\title{
Enhancing client loyalty of advertising agencies: the influence of creativity and inter-firm relationships
}

\author{
Elizabeth Levin
}

Swinburne University of Technology, Melbourne, Australia

Email: elevin@swin.edu.au

\section{Antonio Lobo}

Swinburne University of Technology, Melbourne, Australia

\section{Park Thaichon}

S P Jain School of Global Management, Sydney, Australia

\section{ABSTRACT}

This study develops a model for the drivers of loyalty, drawing literature from both service quality and relationship marketing. It investigates how advertising agencies' creativity and inter-firm relationships influence their clients' perceived value and overall satisfaction, and in turn how these influence clients' loyalty towards advertising agencies. A validated survey instrument was used to collect quantitative data. Responses from 119 clients of advertising agencies were analysed using the Partial Least Square (PLS) technique. The model was robust in that inter-firm relationships, overall satisfaction and value followed by creativity explained $72 \%$ of variation in loyalty. The findings reveal that the inter-firm relationship is a more important determinant of satisfaction with an advertising agency than creativity, however this relationship is reversed when considering clients' value perceptions. Service providers such as advertising agencies need to ensure that they focus on all the aspects of service provision to fulfil varying needs and expectations of their clients.

Keywords: advertising agency, creativity, inter-firm relationships, value, satisfaction, loyalty 


\section{Introduction}

The nature of the advertising industry has changed over the last decade, although its role of communicating with and influencing customers remains unchanged. Advertising agencies offer solutions to marketing problems for businesses, not for profit organisations as well as government (Beverland et al., 2007; Turnbull and Wheeler, 2015). Many larger agencies have purchased boutique or specialist agencies, such as public relations agencies, website development, direct marketing and marketing research firms to ensure that they are able to provide a range of services that their clients expect through a one-stop-shop (Wilson, 2010). Clients are time-precious and do not want to be briefing multiple service providers or negotiating how to divide up their marketing expenditure between the agencies. Hence they prefer to use one full-service agency. Clients seek solutions to problems but are often not sure where the solution lies and which are the most appropriate channels. The twentieth-century agency was focused on creativity, billings and retainers whereas in the twenty-first-century agencies need to work differently with their clients in order to remain relevant and add value.

According to Wilson (2010) having a loyal client base is one of the key success factors for advertising agencies. Margins in the industry are under continual pressure, and it is more profitable for an agency to have a high proportion of their business coming from existing clients which minimises the costs of sourcing and attracting new business. Several authors have empirically demonstrated that customer loyalty is a key factor in improving a company's economic and competitive position. Customer loyalty is important especially during times of economic austerity and increasing competition (Dick and Basu, 1994; Thaichon et al., 2014; Wang and Wu, 2012). This is one of the first studies to combine service quality and relationship marketing literature to develop a conceptual model to explore the drivers of loyalty.

As business decisions have to be rational, advertising agencies like other service providers need to deliver value to their clients. Perceived value drives satisfaction (Patterson and Spreng, 1997) and in turn, loyalty. Customers choose the product or service that offers the best relative value compared to others in their consideration set (Neal, 1999). Overall satisfaction is a cumulative evaluation based on total purchase and consumption experience with a good or service over time (Anderson et al., 1994; Thaichon and Quach, 2015). Satisfaction affects future buying decisions, and satisfied customers are generally loyal, which increases revenue and lowers operating costs. Therefore, higher satisfaction lifts return on investments, stock price and adds market-value for service providers (Anderson et al., 2009; Bayraktar et al., 2012).

Belch et al. (2009) claim that the key reason clients use advertising agencies relates to the specialist knowledge and the objective market analysis they are able to provide, and their ability to draw on experiences gained whilst working for other clients. There is a heightened need for agencies to consider the whole client experience, focusing on understanding and responding to the clients' needs whilst displaying creativity. The relationship between advertising agencies and their clients is based on emotions and feelings as well as economic outcomes. There are agencies which are 
prepared to cut costs and provide discounts to get the job done, but these exchanges focus on shortterm results rather than long-term investments. The quality of the relational exchange between service providers such as advertising agencies and their clients is an important dimension which is likely to influence loyalty.

Therefore, the objectives of this research study are to develop and test a model based on service quality and relationship marketing literature to investigate how advertising agencies' creativity and inter-firm relationships influence their clients' value perceptions and overall satisfaction; and to examine how value perceptions and overall satisfaction influence the loyalty of clients towards their advertising agencies.

This paper comprises seven main sections commencing with a literature review exploring the constructs and developing the hypotheses for the study. The method section discusses how the constructs are operationalised as well as the process involved in data collection. The analysis and results section is presented next and is followed by the discussion section which links the findings to extant literature. Then theoretical and managerial implications are presented. The paper concludes with limitations and recommendations for future research.

\section{Literature Review}

\section{Loyalty}

Loyalty is widely recognised as being one of the most important constructs in the marketing literature (Caceres and Paparoidamis, 2007; Shirin and Puth, 2011; Wang and Wu, 2012). The loyalty of buyers positively affects personal and non-economic satisfaction through ongoing social exchange with a vendor, and consequently, buyers find the overall experience with a seller more satisfying (Lam et al., 2004; Wang and Wu, 2012). Many authors have adopted the two-dimensional construct of loyalty, that is, the inclusion of both behavioural and attitudinal components. The behavioural component refers to repurchase behaviour whilst the attitudinal dimension relates to a commitment to the organisation (La et al. 2005). In this study loyalty, the principle measure of customer retention is conceptualised as being composed of reuse and advocacy.

\section{Perceived value}

There are many reasons why organisations enter and maintain business relationships, but it is unlikely that in a competitive marketplace, organisations would continue to use the services or products of a supplier if they did not receive value through this relationship (Shirin and Puth, 2011; Tam, 2012). The value in the current study is used to represent 'client perceived value'. Paulin et al. (2000) explain that marketing literature regards customer perceived value as: the fundamental basis for marketing (Tam, 2012), a key strategic variable to help explain repeat purchase behaviour, brand loyalty (Patterson and Spreng 1997) and relationship commitment (Thaichon et al., 2014), and a source of competitive advantage (Tam, 2012). Perceived benefits consist of a combination of technical support, physical and service attributes (Thaichon and Quach, 2015). Costs or sacrifices 
include anything which is given up in order to receive the good or service provided and incorporates monetary value or price (Durvasula et al. 2004; Tam, 2012).

\section{Satisfaction}

The important issue of customer satisfaction has been studied since the 1970s (Deng et al., 2010; Thaichon and Quach, 2015). According to Durvasula et al. (2004: 314) 'Customer satisfaction has been regarded as the ultimate business goal'. Several researchers contend that in the professional services area of business, clients tend to remain with the same provider if continually satisfied (Bayraktar et al. 2012). Oliver (1999) claims that satisfaction is a consumer's post-purchase evaluation and incorporates an affective response to the overall experience. Deng et al. (2010) and Eggert and Ulaga (2002) expand on Oliver's definition and contend that cognitive processes underlie the satisfaction construct, whereby perceived performance is compared against some pre-conceived comparison standard. Geyskens et al. (1999: 224) define customer satisfaction in the business-tobusiness (B2B) context as 'a positive affective state resulting from the appraisal of all aspects of a firm's working relationship with another firm'.

\section{Creativity}

Creativity is a broad construct (Lehnert et al. 2014; Michell, 1986) with no consistent views or definition. In this study, creativity comes in many forms and relates to the contribution of creative managers, account planners, and media buyers. Creativity has been conceptualised as well conceived and well-crafted ideas from all facets of the agency to provide a solution to the problem at hand. The key selection criteria in choosing an advertising agency are often concerned with performance factors, such as creativity, the development of fresh ideas and knowledge, and experience within the firm's industry (Turnbull and Wheeler, 2014). Caceres and Paparoidamis (2007) and Simões and Mason (2012) categorised quality as advertising or technical quality, and functional or service quality. They argue that creative aspects are a more important predictor of satisfaction than functional quality. Research suggests that creativity as service performance can increase satisfaction (Beverland et al., 2007; Van Rensburg, 2010) and confidence with the agency (Davies and Palihawadana, 2006). Agencies with a high level of creativity are those which have moved from understanding clients' needs to shaping them, anticipating their clients' needs and taking initiative. Patterson and Spreng (1997) tested the impact of performance on perceptions of perceived value and satisfaction in a B2B context and found strong linkages between the constructs. Van Rensburg (2010) found that core services, incorporating creativity and proactivity, offered by advertising agencies to clients were strongly correlated to satisfaction. Accordingly, the following hypotheses are postulated:

$H_{1 a}$ : The creativity of advertising agencies is positively related to their clients' perceived value.

$H_{1 b}$ : The creativity of advertising agencies is positively related to their client's overall satisfaction. 


\section{Inter-firm relationships}

Relationships are critical to all businesses. Though there are many advantages to developing and sustaining relationships between advertising agencies and their clients, there has been scant research investigating successful relationships (LaBahn and Kohli, 1997; Turnbull and Wheeler, 2014). Much research on client-agency relationships is focused on switching behaviour and the reasons for termination of relationships (Michell, 1986). Whilst general relationship issues are cited as the most important area of client concern during agency reviews, most research on relationships focuses on the supplier side rather than the client side (Karantinou and Hogg, 2009).

As there is no consistency to the conceptualisation of relationships, the current study focuses on relational or emotional and professional elements of relationships between the service provider and client including civility, friendliness and sociability, as well as competence. Paulin et al. (2000) contend that it is important to differentiate between exchanges in industrial or commercial contexts, which are likely to be transaction based, and those that occur through the delivery of professional services, which are more likely to be relational exchanges. Differentiation in business relationships can be researched from a value-based perspective (Ulaga and Eggert, 2006). Effective differentiation must increase customer value by either offering more benefits or decreasing costs for the customer. Suppliers in business relationships often consider that a way to differentiate themselves is through improved customer interactions which have become essential in securing a key supplier position (Ulaga and Eggert, 2006). From a service provider's perspective, there are distinct advantages to building relationships with customers as the key success factor for business performance is a relational exchange (Rajamma et al., 2011). Ulaga and Eggert (2006) assert that relationship benefits represent a larger potential for differentiation than do cost considerations in terms of value in B2B context. Van Rensburg (2010) found that client satisfaction relates to both a combination of service and relationship quality. Thus the following hypotheses are postulated:

$\mathrm{H}_{2 \mathrm{a}}$ : Inter-firm relationships are positively related to advertising agencies' clients' perceived value.

$\mathrm{H}_{2 \mathrm{~b}}$ : Inter-firm relationships are positively related to advertising agencies' clients' overall satisfaction.

\section{Satisfaction, value and loyalty}

Customer satisfaction is core to the development and maintenance of business relationships hence an investigation into the determinants of client loyalty must include assessment of client satisfaction (Geyskens et al., 1999; Lin and Wang, 2006; Oliver, 1999; Patterson and Spreng, 1997). Customer satisfaction does not guarantee relationship continuity (Ulaga and Eggert, 2006), as even satisfied customers have been known to defect or seek alternatives (Ndubisi et al., 2009). However, satisfied customers have positive attitudes towards the service provider which may act as a motivator to recommend the services of the provider, as well as to repurchase from the supplier (Cheng et al., 2008; Lam et al., 2004). Hence customer satisfaction precedes future positive actions on the part of the purchaser. Therefore, the following have been hypothesised: 
$\mathrm{H}_{3}$ : Advertising agency clients' perceived value is positively related to their overall satisfaction.

$\mathrm{H}_{4 a}$ : Advertising agency clients' perceived value is positively related to their loyalty.

$\mathrm{H}_{4 \mathrm{~b}}$ : Advertising agency clients' overall satisfaction is positively related to their loyalty.

Patterson and Spreng (1997) were among the first researchers to undertake empirical research into buyers' perception of value, and combine this with assessments of perceived performance and satisfaction as drivers of repurchase intentions. However the constructs in their model are predominantly cognitive with no relational constructs. Durvasula et al. (2004) using a services marketing approach modelled the antecedents of behavioural and attitudinal loyalty incorporating the dimensions of service quality, value and satisfaction, using two models, one incorporating both direct and indirect relationships, whilst the second was a fully mediated model. Whilst their model includes several evaluative constructs, relational dimensions have been totally ignored. Durvasula et al.'s (2004) model is similar in structure to the one used by Patterson and Spreng (1997) with the key differences being the use of two dimensions to assess loyalty, as well as the direct paths from value to the loyalty constructs. The conceptual model for the study was informed by service quality and relationship marketing literature to fill the identified gaps and is depicted in Figure 1.

Figure 1: Conceptual model for evaluating client-advertising agency relationship

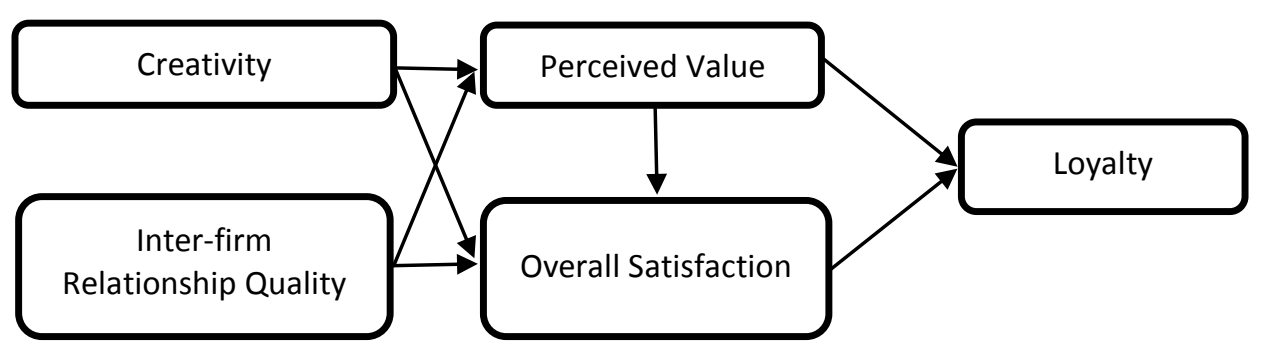

\section{Method}

\section{Measures}

Creativity was assessed via three items based on the work of LaBahn and Kohli (1997) and was expanded to incorporate agency proactivity in line with Durkin and Lawlor (2001), Kupakuwana and van der Berg (2005) and Beverland et al. (2007). Michell (1986) identified the three key elements of the client- agency partnership as creativity, service and relationship dynamics. Wilson and Mummalaneni (1988) contend that service encounters and relationships between individuals from trading organisations enhance inter-organisational communication, understanding and information exchange, thereby strengthening the overall relationship. The inter-firm relationship, based on the construct used by Levin and Lobo (2011) was assessed using 4 items, covering social, personal and professional aspects of the relationship sourced from Kumar et al. (1994), de Ruyter et al. (2001), La et al. (2005) and Moorman et al. (1992). 
Perceived value is a cognitive construct often conceptualised as a trade-off between the sacrifice made to receive the perceived benefits. The three items measuring perceived value were sourced from Doney et al. (2007). Satisfaction, an evaluative construct where an outcome is compared with an expectation or norm, was assessed using four items relating to affective evaluation of various aspects of service provision. These include satisfaction with the personal and professional relationship as well as satisfaction with the services provided. The items were drawn from Lam et al. (2004). A two-dimensional conceptualisation of loyalty has been adopted with the inclusion of behavioural and attitudinal aspects. The six items used to assess loyalty were adapted from Eggert and Ulaga (2002), La et al. (2005), and Patterson and Spreng (1997). The survey items are shown in Table 2.

All the items were measured using a 7-point Likert scale, anchored at one indicating strongly disagree and seven indicating strongly agree. Face and content validity for items in the survey instrument was established as most of them originated from previous empirical and theoretical research. The draft questionnaire was pretested using five marketing academics and industry experts.

\section{Data collection}

The intended target audience was firms which had recently employed the services of an advertising or marketing solutions agency for a project or campaign of strategic importance. Participants were recruited from a list purchased from "Incnet", a business database service providing details for key decision makers in Australia and New Zealand. This database contained names and details for 937 marketing decision makers in Melbourne and Sydney across a variety of industries. This method of recruiting participants is consistent with the key informant technique employed by Eggert and Ulaga (2002) and Patterson and Spreng (1997). Initially, a telephone call was made to each contact person that was followed by an email containing a link to the online survey. Of the 937 company contacts 375 were ineligible to participate due to various reasons such as non-use of external advertising agencies and the key contact no longer being employed. From the remaining 562 companies, 239 attempted to participate. However this was reduced to 179 after the two screening questions. These related to whether the respondent had previously worked with an advertising agency on a project of strategic significance, and the recency of such project work. Finally, 119 responses were used for the analysis. This sample size is typical of research studies undertaken in the professional services context. For example, Patterson and Spreng (1997) with a sample size of 128; Davies and Palihawadana (2006) in the advertising industry with a sample size of 122; and the study by Van Rensburg (2010) with a sample size of 116.

Initial contact was made with a single key informant who held a senior marketing role in the organisation. Over $90 \%$ of the respondents indicated that they held executive or very senior positions with a significant level of responsibility for the project undertaken. $42.5 \%$ indicated that they had full responsibility. It can, therefore, be concluded that they were able to provide authoritative information about the manner in which the projects were planned and implemented, and details about the relationship between the service provider and the client organisations. Annual 
spend with advertising agencies varied, with $63.9 \%$ of respondents spending less than $\$ 1$ million, whilst $11.3 \%$ spent over $\$ 10$ million per annum. Over $80 \%$ had parent companies registered in Australia or New Zealand. Details of the size of the responding organisations by annual turnover and employee numbers are provided in Table 1.

Table 1: Sample structure

\begin{tabular}{|c|c|c|}
\hline \multirow[t]{2}{*}{ Demographic profile } & \multicolumn{2}{|c|}{ No. of participants } \\
\hline & $(N=119)$ & $\%$ \\
\hline \multicolumn{3}{|l|}{ Job specification of respondents } \\
\hline Director / CEO/General manager & 38 & 32 \\
\hline Marketing manager or marketing executive & 70 & 58.8 \\
\hline Advertising, product or brand manager/ coordinator & 10 & 8.2 \\
\hline Advertising or marketing personnel/assistant & 1 & 1 \\
\hline \multicolumn{3}{|l|}{ Size of organisations as measured by annual revenue } \\
\hline Less than $\$ 50$ million & 26 & 21.8 \\
\hline$\$ 50$ to $<\$ 100$ million & 13 & 10.9 \\
\hline$\$ 100$ to $<\$ 500$ million & 24 & 20.2 \\
\hline$\$ 500$ to $<\$ 1000$ million & 13 & 10.9 \\
\hline$\$ 1$ to $<\$ 2$ billion & 9 & 7.6 \\
\hline$\$ 2$ billion and over & 12 & 10.1 \\
\hline Missing & 22 & 18.5 \\
\hline \multicolumn{3}{|l|}{ Size of organisations as measured by No. of employees } \\
\hline $0-<100$ & 26 & 21.6 \\
\hline $100-<250$ & 16 & 13.4 \\
\hline $250-<500$ & 25 & 20.6 \\
\hline $500-<1000$ & 7 & 6.2 \\
\hline $1000-<2000$ & 12 & 10.3 \\
\hline $2000-<5000$ & 20 & 16.5 \\
\hline More than 5000 & 13 & 11.3 \\
\hline
\end{tabular}

\section{Analysis and results}

Vinzi et al. (2010: 2) claim that 'PLS-PM is a statistical approach for modelling complex multivariate relationships among observed and latent variables'. PLS is a non-parametric component based approach (Garson, 2012) and is suitable for exploratory or predictive modelling. PLS is suitable for application with small sample sizes (Chin, 1998). Barclay et al. (1995) suggest that the minimum sample size is ten times the maximum number of paths in the inner model when one is using reflective indicators. All constructs used in the current study were reflective latent variables. The inner model contains seven paths and hence the current sample size exceeds the stipulated minimum.

Smart PLS version 2 software was employed to analyse the collected data. All default settings were preserved, with the initial perceived value for each outer weight set at 1 . No weighting scheme was used and the maximum number of iterations was 500 . There were 500 bootstrap samples used with 
the number of bootstrap cases set to equal the number of valid observations; that is 119 (Hair et al., 2011). Anderson and Gerbig (1988) recommend a two stage analysis process consisting of testing the measurement or outer model, followed by the examination of the structural or inner model.

\section{Outer model evaluation}

According to Hair et al. (2011) evaluation of the outer model with reflective latent variables involves assessment of reliability and validity. Firstly, indicator reliability needs to be assessed with all standardised indicator loadings above 0.7 (Fornell and Larcker, 1981). Internal consistency should be assessed using composite reliability score (Hair et al., 2011) which should also be at least 0.7 (Bagozzi and Yi, 1988). Furthermore, convergent validity should be checked. Factor loadings should all be high and significant, AVE (average variance extracted) should be greater than 0.5. All these conditions have been met. Details of measurement model validation are provided in Table 2. Hence construct reliability and validity have been confirmed.

Table 2: Instrument items and reliability indices

\begin{tabular}{|c|c|c|c|c|c|}
\hline & Items & $\mathrm{FL}$ & $\alpha$ & CR & AVE \\
\hline \multirow[t]{3}{*}{ CRE } & Our advertising agency consistently provides a high standard of creative work & .947 & .902 & .939 & .837 \\
\hline & Our advertising agency's creative work consistently meets our needs & .958 & & & \\
\hline & $\begin{array}{l}\text { Our agency is proactive and offers new suggestions to improve our } \\
\text { performance }\end{array}$ & .834 & & & \\
\hline \multirow[t]{3}{*}{ IFR } & It is pleasant working with our advertising agency. & .924 & .883 & .928 & .812 \\
\hline & $\begin{array}{l}\text { My organisation believes it has benefited from a long-term relationship with } \\
\text { our advertising agency }\end{array}$ & .838 & & & \\
\hline & My interactions with our advertising agency are productive & .937 & & & \\
\hline \multirow[t]{3}{*}{ VAL } & Compared to the price we paid, we received good quality & .955 & .960 & .974 & .926 \\
\hline & We got perceived value for money with this project & .956 & & & \\
\hline & $\begin{array}{l}\text { On this project our advertising agency delivered us superior net perceived } \\
\text { value }\end{array}$ & .975 & & & \\
\hline \multirow[t]{3}{*}{ SAT } & $\begin{array}{l}\text { In general, my organisation is completely satisfied with the services offered } \\
\text { by our advertising agency }\end{array}$ & .960 & .955 & .971 & .917 \\
\hline & $\begin{array}{l}\text { Overall, my organisation is very satisfied with its relationship with our } \\
\text { advertising agency }\end{array}$ & .961 & & & \\
\hline & Overall, our advertising agency is a good company with which to do business & .952 & & & \\
\hline \multirow[t]{5}{*}{ LOY } & $\begin{array}{l}\text { My organisation would be willing to provide our advertising agency with a } \\
\text { testimonial }\end{array}$ & .861 & .913 & .935 & .745 \\
\hline & We often recommend our advertising agency to other people & .905 & & & \\
\hline & $\begin{array}{l}\text { We take pride in telling other people about our experiences with our } \\
\text { advertising agency }\end{array}$ & .777 & & & \\
\hline & $\begin{array}{l}\text { My organisation would not seek the services of any other agency for services } \\
\text { that our advertising agency are able to provide }\end{array}$ & .889 & & & \\
\hline & $\begin{array}{l}\text { For the next appropriate marketing project my organisation will use the } \\
\text { same advertising agency }\end{array}$ & .876 & & & \\
\hline
\end{tabular}

Notes: $\mathrm{FL}=$ factor loadings, $\alpha=$ Cronbach's alpha, $\mathrm{CR}=$ Construct reliability, $\mathrm{AVE}=$ Average variance extracted, $\mathrm{CRE}=$ Creative; IFR = Inter-firm relationship; VAL = Value; SAT = Satisfaction; LOY = Loyalty. 
Discriminant validity was assessed at the item and construct level using Fornell and Larcker (1981) criterion which utilises a comparison of the average variance extracted (AVE) with the correlations. Discriminant validity is evident when a construct shares more variance with its internal measures than with other constructs in the model, or the AVE is greater than the squared correlation, as shown in Table 3.

Table 3 Table 3: Discriminant validity: using Fornell-Larcker criterion

\begin{tabular}{lccccc}
\hline & Creativity & Inter-firm Relationship & Perceived value & Satisfaction & Loyalty \\
\hline Creativity & $\mathbf{0 . 8 3 7 8}$ & & & & \\
Inter-firm relationship & 0.5285 & $\mathbf{0 . 8 1 2 3}$ & & & \\
Perceived value & 0.6037 & 0.5776 & $\mathbf{0 . 9 2 6 6}$ & & \\
Satisfaction & 0.6839 & 0.7921 & 0.6432 & $\mathbf{0 . 9 1 7 8}$ & \\
Loyalty & 0.4624 & 0.6068 & 0.6178 & 0.6691 & $\mathbf{0 . 7 4 5 1}$ \\
\hline
\end{tabular}

Notes: Diagonals contain AVE. Cells contain squared correlations

\section{Inner model evaluation}

The bootstrap procedure in Smart PLS can be used to generate t-statistics (Chin, 1998) to overcome the disadvantage of non-parametric methods having no formal tests of significance. All parameter estimates are significant at $1 \%$ level as shown in Table 4; hence all hypotheses are supported.

\section{Table 4: Regression coefficients of hypothesised pathways}

\begin{tabular}{lll}
\hline Structural pathways/Hypotheses & $\begin{array}{l}\text { Standardised path } \\
\text { coefficient }\end{array}$ & $\begin{array}{l}\text { t perceived } \\
\text { value }\end{array}$ \\
\hline $\mathrm{H}_{1 \mathrm{a}}:$ Creativity $\rightarrow$ perceived value & 0.469 & $5.20^{*}$ \\
$\mathrm{H}_{1 \mathrm{~b}}:$ Creativity $\rightarrow$ satisfaction & 0.271 & $3.45^{*}$ \\
$\mathrm{H}_{2 \mathrm{a}}:$ Inter-firm relationship $\rightarrow$ perceived value & 0.419 & $4.63^{*}$ \\
$\mathrm{H}_{2 \mathrm{~b}}:$ Inter-firm relationship $\rightarrow$ satisfaction & 0.603 & $5.80^{*}$ \\
$\mathrm{H}_{3}:$ Perceived value $\rightarrow$ satisfaction & 0.138 & $2.36^{*}$ \\
$\mathrm{H}_{4 \mathrm{a}}:$ Perceived value $\rightarrow$ loyalty & 0.365 & $4.24^{*}$ \\
$\mathrm{H}_{4 \mathrm{~b}}:$ Satisfaction $\rightarrow$ loyalty & 0.528 & $5.97^{*}$ \\
\hline
\end{tabular}

Notes: $* p<0.01$

As hypothesised in $\mathrm{H}_{1 \mathrm{a}}$ and $\mathrm{H}_{1 b}$, creativity of advertising agencies is positively and significantly related to their clients' value perception ( $\beta=0.47, p<0.01)$, and satisfaction $(\beta=0.27, p<0.01)$. Also as hypothesised in $\mathrm{H}_{2 a}$ and $\mathrm{H}_{2 b}$, inter-firm relationships are positively and significantly related to clients' value perception ( $\beta=0.42, p<0.01$ ), and satisfaction $(\beta=0.60, p<0.01) . H_{3}$ which assessed the relationship between value perception and satisfaction is supported $(\beta=0.14, p<0.01)$. $H_{4 a}$ stated that value perceptions are positively related to client loyalty and this hypothesis is supported $(\beta=$ $0.37, p<0.01$ ), as is $\mathrm{H}_{4 b}$ which stated that overall satisfaction is positively related to client loyalty ( $\beta$ $=0.53, \mathrm{p}<0.01)$. 
Unlike covariance based methodologies PLS does not provide the goodness of fit statistics for the model. Instead, it is instructive to examine the $\mathrm{R}^{2}$ values of the individual dependent variables (Whittaker et al., 2007). The results indicate that the model possesses considerable predictive powers as $R^{2}$ varies from 0.678 to 0.874 . More specifically, clients' evaluation of their advertising agency's creativity together with their evaluation of the relationship between client and service provider explains $67.8 \%$ of the variation in value. Similarly, clients' evaluation of the same two facets of the client-advertising agency relationship explains $87.4 \%$ of the variation in satisfaction. The overall model explains a substantial proportion of the variation in client loyalty that is $72.2 \%$. The final model is shown in Figure 2.

Figure 2: Final PLS Model

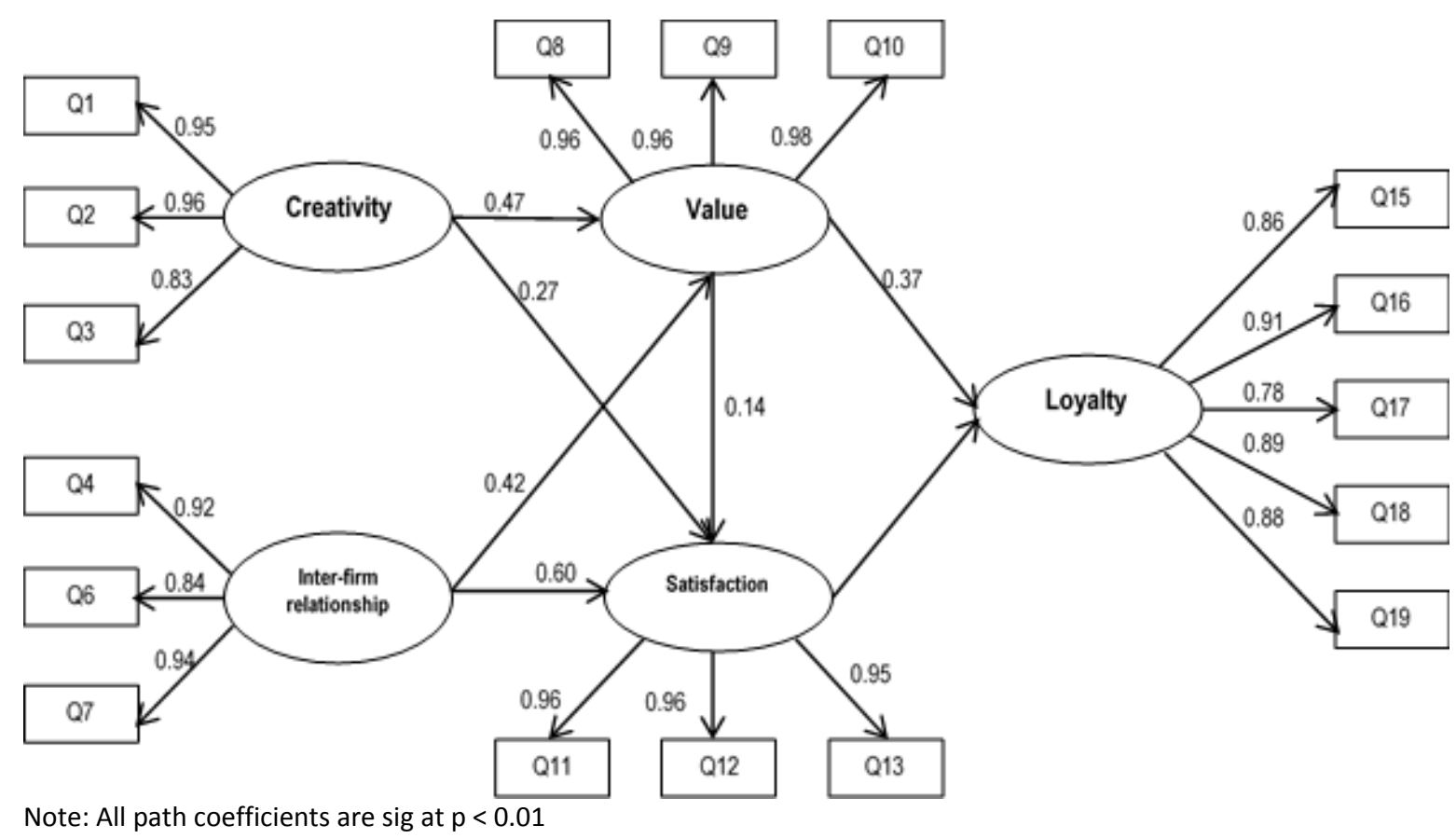

Table 5 contains the total effects, which is a combination of direct and indirect effects of the various constructs on one another. The highest effect is from inter-firm relationships to satisfaction, followed by satisfaction to loyalty, whilst the lowest total effects are from perceived value to satisfaction.

Table 5: Total effects

\begin{tabular}{llll}
\hline & Perceived value & Satisfaction & Loyalty \\
\hline Creativity & 0.4686 & 0.3350 & 0.3479 \\
Inter-firm relationship & 0.4190 & 0.6604 & 0.5018 \\
Perceived value & & 0.1377 & 0.4376 \\
Satisfaction & & & 0.5284 \\
\hline
\end{tabular}




\section{Discussion}

This study examined the influence of creativity and inter-firm relationships in the client-advertising agency context. The findings revealed that clients perceive that their advertising agencies are providing them with value through creativity aspects as well as inter-firm relationships. When considering the two direct antecedents of perceived value, this study has demonstrated that creativity is a more important determinant of client's value perceptions than inter-firm relationships (see Table 5). The only two studies which have included creativity in a B2B relationship management model are those of Caceres and Paparoidamis (2007) and LaBahn and Kohli (1997). However, neither of these studies incorporated an assessment of perceived value. Czepiel (1990: 17) contends that 'service marketers need to study how economic exchange is played out against a background of social exchange'. The current study supports the nexus between economic and social exchange in the client-advertising agency context.

Jayawardhena et al. (2007: 581) found that service performance quality positively influences overall satisfaction which confirms 'the importance of personal customer-employee interactions in developing positive emotive judgements'. This impacts on long-term perceptions of the firm and plays an important role in relationship management and continuance of business relationships. The findings of this study revealed that creativity and inter-firm relationships are the two directly significant antecedents to satisfaction. The less structured aspects of the service provision are the ones that lead to a positive affective state.

According to social science theory, affective responses are triggered through cognitive thought processes (Ellis, 1962). The suggested relationship that perceived value is positively associated with satisfaction has been supported in various contexts by Durvasula et al. (2004), Eggert and Ulaga (2002), Lam et al. (2004), Patterson and Spreng (1997) and Whittaker et al. (2007) and is further supported in the current study. Marketers should be aware that both perceived value and satisfaction have a crucial role in fostering client-agency relationships.

Several studies have supported the relationship between perceived value and behavioural intentions and attitudinal loyalty. The findings from the current study support the direct relationship between perceived value and future intentions as one logically expects in commercial and professional relations. Furthermore, the relationship between evaluative-based satisfaction and loyalty is strongly supported.

The antecedents and consequences of client perceived value and satisfaction have been evaluated using empirical research in order to develop a deeper understanding of the client-advertising agency relationship. The model exhibited strong explanatory powers for perceived value $\left(R^{2}=0.678\right)$, satisfaction $\left(R^{2}=0.874\right)$ and loyalty $\left(R^{2}=0.722\right)$. Overall, the highest total effects on client loyalty were satisfaction, followed by inter-firm relationships, perceived value and finally creativity. 


\section{Theoretical implications}

The objective of this study was to investigate how the two core elements of a service providers' offerings, namely the service they deliver and the relations developed with the client, influence the clients' value perceptions and overall satisfaction and ultimately the impact these have on loyalty. This study was among the first to develop a model for the drivers of loyalty, drawing from literature in two key areas: service quality and relationship marketing. Creative competence plays an important role in the evaluation of value and development of satisfaction, which in turn build client loyalty. There is scant literature relating to social exchange between customers and service providers and the association of interpersonal relationships with loyalty. The inter-firm relationship has been incorporated into the model and proved to be a powerful predictor of value, satisfaction, and loyalty. Service encounters between clients and agencies facilitate the development of these bonds.

The results of this study reveal that satisfaction of clients' needs and expectations is paramount for ongoing business relationships. In addition, an agency that is deemed to provide high value has a competitive advantage as they have achieved the desired results through their creative prowess. Value is directly related to loyalty. Moreover, perceived value and satisfaction are interlinked. If a supplier provides good value, the client is more likely to possess positive affective emotions, leading to satisfaction. Whilst previous studies have focused on the effect of either value or satisfaction on loyalty both play an important part in the B2B context, and hence neither should be omitted.

\section{Implications for Business Practice}

Advertising agencies need to focus on all the aspects of the service provision that are valued by their client base. These are satisfaction with the services provided, specifically the relationship with the agency and its staff, and an understanding and meeting of expectations; developing and maintaining strong inter-firm links which incorporate pleasant and productive working relationships from which both parties ultimately benefit; and providing perceived value for money services to clients. As creativity was found to be important, agencies should focus on this core performance of their service in order to increase relationship quality and loyalty. Agencies are encouraged to engage clients in their creative process so that their clients understand the procedure of campaign creation, thus strengthening the relationships between firms.

Inter-firm aspects are very important as these are also the key drivers of satisfaction. Client perceptions of their advertising agencies are formed through a series of interactions with employees of the service provider. Hence every contact between the agency and its clients has the potential to improve or damage the business relationship. Relationship management is, therefore, the responsibility of all agency staff whether they are senior partners or more junior account executives. Agencies need to focus their attention on aspects that matter to the clients to maintain business associations and custom as well as to reduce churn and alternate seeking behaviour. Loyalty depends on the total service package rather than on specific elements. 


\section{Limitations and future research}

The findings of this study are bound by the context of the client-advertising agency relationship in Australia, which therefore compromises on its generalisability. To an extent, the cross-sectional research design of this study was also a limitation as the study was unable to capture the effect of time on client responses and on their relationships with advertising agencies. As indicated, a survey strategy was employed for this study. The survey consisted predominantly of scaled items to allow for analysis using PLS. Consequently, the qualitative element of the research was limited.

Future longitudinal studies would be useful to test the efficacy and validity of the conceptual model in this study. Also, future segmentation studies based on mature and new advertising agency-client relationships might reveal interesting findings. Whilst the context of the current study is the advertising industry, it would be interesting to test the model in other service provision contexts substituting technical service quality in place of creativity.

\section{References}

Anderson, E., Fornell, C. and Lehmann, D.R. (1994) Customer satisfaction, market share and profitability: Findings from Sweden. Journal of Marketing, 58(July) pp 53-66.

Anderson, J. and Gerbing, D. (1988) Structural equation modeling in practice: A review and recommended two-step approach. Psychological Bulletin, 103(3) pp 411-423.

Anderson, J., Narus, J. and Narayandas, D. (2009) Business Market Management. Pearson Prentice Hall, Upper Saddle River, NJ.

Bagozzi, R. and Yi, Y. (1988) On the evaluation of structural equation models. Journal of the Academy of Marketing Science, 16(1) pp 74-94.

Barclay, D., Higgins, C. and Thompson, R. (1995) The partial least squares approach to causal modeling: personal computer adoption and use as illustration. Technology Studies, 2(2) pp 285309.

Bayraktar, E., Tatoglu, E., Turkyilmaz, A., Delen, D. and Zaim, S. (2012) Measuring the efficiency of customer satisfaction and loyalty for mobile phone brands with DEA. Expert Systems with Applications, 39(1) pp 99-106.

Belch, G., Belch, M., Kerr, G. and Powell, I. (2009) Advertising and Promotion: An Integrated Marketing Communications Perspective. McGraw-Hill, Sydney.

Beverland, M., Farrelly, F. and Woodhatch, Z. (2007) Exploring the dimensions of proactivity within advertising agency-client relationships. Journal of Advertising, 36(4) pp 49-60.

Caceres, R. and Paparoidamis, N. (2007) Service quality, relationship satisfaction, trust, commitment and business-to-business loyalty. European Journal of Marketing, 41(7-8) pp 836-867.

Cheng, T., Lai, L. and Yeung, A. (2008) The driving forces of customer loyalty: a study of internet service providers in Hong Kong. International Journal of E-Business Research, 4(4) pp 26-42. 
Chin, W. (1998) The partial least squares approach for structural equation modeling. In G. Marcoulides (ed.) Modern Methods for Business Research. Erlbaum, Hillsdale, NJ.

Czepiel, J. (1990) Service encounters and service relationships: Implications for research. Journal of Business Research, 20(1) pp 13-21.

Davies, M. and Palihawadana, D. (2006) Developing a model of tolerance in client-agency relationships in advertising. International Journal of Advertising, 23(3) pp 381-407.

de Ruyter, K., Moorman, L. and Lemmink, J (2001) Antecedents of commitment and trust in customer-supplier relationships in high technology markets. Industrial Marketing Management, 30(3) pp 271-286.

Deng, Z., Lu, Y., Wei, K. and Zhang, J. (2010) Understanding customer satisfaction and loyalty: An empirical study of mobile instant messages in China. International Journal of Information Management, 30(4) pp 289-300.

Dick, S. and Basu, K. (1994) Customer loyalty: Toward an integrated conceptual framework. Journal of the Academy of Marketing Science, 22(2) pp 99-113.

Doney, P. M., Barry, J. M. and Abratt, R. (2007) Trust determinants and outcomes in global B2B services. European Journal of Marketing, 41(9/10) pp 1096-1116.

Durkin, M. and Lawlor, M. (2001) The implications of the Internet on the advertising agency-client relationship. Service Industries Journal, 2(2) pp 175-190.

Durvasula, S., Lysonski, S., Mehta, S. and Tang, B. (2004) Forging relationships with services: The antecedents that have an impact on behavioural outcomes in the life insurance industry. Journal of Financial Services Marketing, 8(4) pp 314-326.

Eggert, A. and Ulaga, W. (2002) Customer perceived value: A substitute for satisfaction in business markets? Journal of Business and Industrial Marketing, 17(2/3) pp 107-118.

Ellis, A. (1962) Reason and Emotion in Psychotherapy. Lyle Stuart, New York.

Vinzi, V., Chin, W., Henseler, J. and Wang, H. (eds) (2010) Handbook of Partial Least Squares: Concepts, Methods and Applications. Springer, Heidelberg.

Fornell, C. and Larcker, D. (1981) Evaluating structural equation models and unobservable variables and measurement error. Journal of Marketing Research, 18(February) pp 39-50.

Garson, G. (2012) Partial Least Squares Path and Regression Modeling. Retrieved 12 February 2014 from < http://faculty.chass.ncsu.edu/garson/PA765/pls.bak >.

Geyskens, I., Steenkamp, J-B. and Kumar, N. (1999) A meta-analysis of satisfaction in marketing channel relationships. Journal of Marketing Research, 36(2) pp 223-238.

Hair, J., Ringle, C. and Sarstedt, M. (2011) PLS-SEM: indeed a silver bullet. Journal of Marketing Theory and Practice, 19(2) pp 139-151.

Jayawardhena, C., Souchon, A., Farrell, A. and Glanville, K. (2007) Outcomes of service encounter quality in a business-to-business context. Industrial Marketing Management, 36(5) pp 575-588.

Karantinou, K. and Hogg, M. (2009) An empirical investigation of relationship development in professional business services. Journal of Services Marketing, 23(4) pp 249-260. 
Kumar, N., Hibbard, J. and Stern, L. (1994) The nature and consequences of marketing channel intermediary commitment. Marketing Science Institute, Cambridge, USA

Kupakuwana, P. and van der Berg, G. (2005). The goalposts for project success have moved: A marketing view. Cost Engineering, 47(5) pp 28-34.

La, K., Walker, R. and Kam, B. (2005) Customer loyalty in e-retailing: An exploratory study. Journal of Internet Marketing and Advertising, 2(3) pp 237-258.

LaBahn, D. and Kohli, C. (1997) Maintaining client commitment in advertising agency-client relationships. Industrial Marketing Management, 26(6) pp 497-508.

Lam, S., Shankar, V., Erramilli, M. and Murthy, B. (2004) Customer perceived value, satisfaction, loyalty, and switching costs: An illustration from a business-to-business service context. Journal of the Academy of Marketing Science, 32(3) pp 293-311.

Lehnert, K., Till, B. and Ospina, J. (2014) Advertising creativity: the role of divergence versus meaningfulness. Journal of Advertising, 43(3) pp 274-285.

Levin, E. and Lobo, A. (2011) Clients' expectations of their advertising agencies: creativity and relationship management. Presented to Australian and New Zealand Marketing Academy Conference, Perth, Australia, November.

Lin, H-H. and Wang, Y-S. (2006) An examination of the determinants of customer loyalty in mobile commerce contexts. Information and Management, 43(3) pp 271-282.

Michell, P. (1986) Auditing of agency-client relations. Journal of Advertising Research, 26(6) pp 2941.

Moorman, C., Zaltman, G. and Deshpande, R. (1992) Relationships between providers and users of market research: The dynamics of trust within and between organizations. Journal of Marketing Research, 29(3) pp 314-328.

Ndubisi, N., Malhotra, N. and Wah, C. (2009) Relationship marketing, customer satisfaction and loyalty: A theoretical and empirical analysis from an Asian perspective. Journal of International Consumer Marketing, 21(1) pp 5-16.

Neal, W. (1999) Satisfaction is nice, but value drives loyalty. Marketing Research, 11(Spring) pp 2023.

Oliver, R. (1999) Whence consumer loyalty? Journal of Marketing, 63(1) pp 33-44.

Patterson, P. and Spreng, R. (1997) Modelling the relationship between perceived value, satisfaction and repurchase intentions in a business to business, service context: An empirical examination. International Journal of Service Industry Management, 8(5) pp 414-434.

Paulin, M., Fergusson, R. and Payaud, M. (2000) Business effectiveness and professional service personnel: Relational or transactional managers? European Journal of Marketing, 34(3/4) pp 453-469.

Rajamma, R., Zolfagharian, M. and Petlon, L. (2011) Dimensions and outcomes of B2B relational exchange: A meta-analysis. Journal of Business and Industrial Marketing, 26(2) pp 104-114.

Shirin, A. and Puth, G. (2011) Customer satisfaction, brand trust and variety seeking as determinants of brand loyalty. African Journal of Business Management, 5(30) pp 11899-11915. 
Simões, C. and Mason, K. (2012) Informing a new business-to-business relationship: Corporate identity and the emergence of a relationship identity. European Journal of Marketing, 46(5) pp 684-711.

Tam, J. (2012) Linking perceived service quality to relational outcomes in a Chinese context. Journal of International Consumer Marketing, 24(1-2) pp 7-23.

Thaichon, P., Lobo, A., Prentice, C. and Quach, T. (2014) The development of service quality dimensions for Internet Service Providers: Retaining customers of different usage patterns. Journal of Retailing and Consumer Services, 21(6) pp 1047-1058.

Thaichon, P. and Quach, T. (2015) The relationship between service quality, satisfaction, trust, value, commitment and loyalty of Internet service providers' customers. Journal of Global Scholars of Marketing Science, 25(4) pp 295-313.

Turnbull, S. and Wheeler, C. (2014) Exploring advertiser's expectations of advertising agency services. Journal of Marketing Communications, pp 1-15:

http://dx.doi.org/10.1080/13527266.2014.920902

Turnbull, S. \& Wheeler, C. (2015) The advertising creative process: A study of UK agencies. Journal of Marketing Communications, pp 1-19: http://dx.doi.org/10.1080/13527266.2014.1000361.

Ulaga, W. and Eggert, A. (2006) Relationship perceived value and inter-firm relationships: Broadening the nomological network of business-to-business relationships. European Journal of Marketing, 40(3/4) pp 311-327.

Van Rensburg, M. (2010) Dimensions of advertising agency client satisfaction. Journal of Contemporary Management, 7(1) pp 549-573.

Wang, C. and Wu, L. (2012) Customer loyalty and the role of relationship length. Managing Service Quality: An International Journal, 22(1) pp 58-74.

Whittaker, G., Ledden, L. and Kalafatis, S. (2007) A re-examination of the relationship between perceived value, satisfaction and intention in business services. Journal of Services Marketing, 21(5) pp 345-357.

Wilson, D. and Mummalaneni, V. (1988) Modeling and measuring buyer-seller relationships. (Unpublished working paper) Institute for the Study of Business Markets, Pennsylvania State University, University Park, Pennsylvania.

Wilson, M. (2010) Battling Low Demand: Clients Cut Advertising Budgets Amid Weaker Consumer Spending. IBISWorld Industry Report L7851 Advertising Services in Australia, IBISWorld, Los Angeles, USA 